\title{
Editorial, March 2020
}

\section{Clare Chambers ${ }^{1} \cdot$ Philip Cook $^{2} \cdot$ Sune Lægaard ${ }^{3}$}

Published online: 8 April 2020

(c) Springer Nature B.V. 2020

Res Publica, now in its 26th year, has been steadily building a reputation as the journal that publishes excellent work in moral, legal, and political philosophy from established scholars as well as new voices. Our submission rates have increased dramatically, meaning that our acceptance rate is now 17\%. In 2019, the journal had more than 96,000 full-text article downloads. We strongly encourage the submission of new work, particularly from women, as we endeavour to improve the gender balance of the authors we publish.

We are delighted to announce several new members of our editorial team.

Clare Chambers (University of Cambridge, UK), formerly an Associate Editor, joins Sune Lægaard (Roskilde University, Denmark) and Philip Cook (University of Edinburgh, UK) as Editor-in-Chief. Her main interests are: contemporary feminist theory, including marriage and personal relationships, the body, beauty and appearance, and liberal and radical feminism; contemporary liberal theory, including equality, autonomy, multiculturalism, and Rawlsian theory; and theories of social construction, including feminist and post-structural philosophy. She is the author of Against Marriage: An Egalitarian Defence of the Marriage-Free State (Oxford University Press, 2017); Sex, Culture, and Justice: The Limits of Choice (Penn State University Press, 2008); and Teach Yourself Political Philosophy: A Complete Introduction (with Phil Parvin, Hodder, 2012). She is currently writing Intact: The Unmodified Body, under contract with Allen Lane.

Res Publica is also delighted to welcome five new Associate Editors.

Christie Hartley (Georgia State University, USA) specialises in social and political philosophy, feminist philosophy, and ethics, including disability, reciprocity, and contractualism. She is the author of Equal Citizenship and Public Reason: A Feminist Political Liberalism (with Lori Watson, Oxford University Press, 2018). She is currently writing a book defending marriage for Routledge.

Clare Chambers

cec66@cam.ac.uk

1 Cambridge, UK

2 Edinburgh, UK

3 Roskilde, Denmark 
Patrick Lenta (University of Technology Sydney, Australia) has research interests in the fields of jurisprudence, applied ethics, comparative constitutional law, transitional justice, and law and literature. He is the author of Corporal Punishment: A Philosophical Assessment (Routledge, 2018). He is currently working on rationales for forbearing punishment.

Dorota Mokrosinska (Leiden University, NL) works on topics in political philosophy and public ethics, with a particular focus on secrecy and transparency in democratic politics, political obligation, political legitimacy, privacy and media ethics. She is the author of Rethinking Political Obligation: Moral Principles, Communal Ties, Citizenship (Palgrave Macmillan, 2012). She is currently the director of the ERC StG project entitled 'Democratic Secrecy' and is writing Secrecy and Democracy: Philosophical Inquiry for Routledge.

Phil Parvin (Loughborough University, UK) specialises in political theory, democratic theory, public policy, and democratic theory, with a particular interest in the way that political theory and political practice interact. He is the author of Karl Popper (Continuum, 2010; Bloomsbury, 2013) and Teach Yourself Political Philosophy: A Complete Introduction (with Clare Chambers, Hodder, 2012). He is currently writing Hidden in Plain Sight: Dark Money, Representation, and Power in 21 st Century Democracy.

Avia Pasternak (University College London, UK) researches a variety of topics in political philosophy, with primary interest in political obligations and collective responsibility in unjust states. She is the author of many articles and chapters on these and other topics in political philosophy, and is currently working on the permissibility of riots as a form of protest in unjust democracies. She is also writing Responsible Citizens Irresponsible States: Should Citizens Pay for their State Wrongdoings? for Oxford University Press.

These new Associate Editors join our existing editorial team: Alasdair Cochrane (University of Sheffield, UK), Chiara Cordelli (University of Chicago, USA), Candice Delmas (Northeastern University, USA), Ben Saunders (University of Southampton, UK), Kristin Voigt (McGill University, Canada), and our Book Review Editor Jesse Tomalty (University of Bergen, Norway). We are sorry to lose Göran Duus-Otterström (University of Gothenburg, Sweden) and thank him for his excellent work during his five years as Associate Editor of Res Publica.

Publisher's Note Springer Nature remains neutral with regard to jurisdictional claims in published maps and institutional affiliations. 